\title{
RISK-TAKING AND STUDENTS' SPEAKING ABILITY: DO THEY CORRELATE?
}

\author{
Lilis Suryani $^{1}$, Ningtyas Orilina Argawati ${ }^{2}$ \\ suryani.lies3@gmail.com, tyas.orilina@gmail.com
}

\author{
IKIP SILIWANGI
}

\begin{abstract}
The students' speaking ability somehow depends on some psychological issues such as motivation, self-esteem, or risk-taking. This research aims on examining the correlation of students' speaking skill especially with their level of risk-taking. The method used in this research is quantitative research method with correlational design. The Null hypothesis was "there is no correlation between Risk-taking and Speaking Ability". The researchers used speaking test and questionnaire about risk-taking as the instruments to gather the data. Before examining the correlation between those two variables, the normality test was conducted. The result showed that the data were in normal distribution so that the analysis was statistically continued using Pearson Product Moment. From the calculation, sig. 2-tailed of both risk-taking and speaking were 0.000 which was lower than the level of significance (0.05). It means that the Null hypothesis is rejected and the final result told that there is a correlation between Risk-Taking and Speaking Ability. While the Pearson correlation reached the point of 0.685 which means that the correlation between those two was large. Finally, we could conclude that risk-taking can be an issue to take into account on choosing some methods of teaching speaking.
\end{abstract}

Keywords: Risk-Taking, Speaking capability, Correlation design.

\section{A. INTRODUCTION}

As a language teacher, one should understand some psychological issues relate to their students during their learning process. One of those psychological issue is their level of Risk-taking. Risk-taking is a willingness of the students to make a decision involving something new and different without putting the primary focus on success or failure (Bang, 1999:13). Every student has his or her own level of risk-taking. It will definitely influence their way of learning language.

Risk-taking also affects the students' way of learning for basic skills, especially productive skills such as speaking and writing. In writing skill, students perform the act of communication in the form of written text to accomplish goal and extending and deepening the students' knowledge (Argawati \& Suryani, 2017). Therefore, on writing, a mistake can be minimalize since we can evaluate our work. It does not go the same as speaking. Something we have already said will be considered an answer, and if the answer is wrong it will affect the students feeling to re-state their sentence. That is why the level of risk-taking does play role in speaking. 
Cervantes (2013) found that if risk takers seek more opportunities to use the target language, it can be argued that they will learn more and improve their language proficiency significantly. When students speak, they test out their hypotheseabout the language. If learning is the result of taking risks, then risk taking is worth trying. It goes the same way as speaking.

Speaking is a prerequisite skill that should be learnt by the students. It is supported by Boonkit (2010), speaking is one of four macro skills to be developed as means of effective communication in both first and second language contexts. It means that speaking as the basic skill for the students to communicate effectively. Moreover, speaking in college has reached the level of real communication where they have to implemented their skill to the real life and get used to use it in any situations (Argawati \& Syahrizal, 2016). In fact, the students have limited exposure in speaking. This is in line with this theory, students who study English as foreign language (EFL) usually have limited opportunities to speak English outside of the classroom and also limited exposure to English speakers or members of the international community (Zhang, 2009).

Relating to the statement above, the researchers come to the thinking that speaking skill is considered difficult for almost language learners in Indonesia. Most students say that speaking needs not only skill but also brave to deliver the speech. This is in line with Maeng (2008) who believes that based on four skills, speaking becomes the most stressful for the students. Therefore, teachers need to seek an appropriate method of teaching to solve the problem

However, seeking new method to see the appropriateness of it with the students in a particular classroom is not a piece of a cake. Teachers need to analyse and observe the condition of the students before they determine the method to be applied. One of the students condition can be related with the psychological variable, in this case, risk- taking.

From the background explained above, the researchers tend to conduct research to know whether or not there is a positive correlation between risk-taking and the students' speaking capability, especially on the second semester students of IKIP Siliwangi. The Null hyphotesis arranged was there is no correlation between Risk- taking and Speaking Ability.

\section{B. LITERATURE REVIEW}

\section{Speaking ability}

Speaking is the first mode in which children acquire language (Hasanah, 2017). They first acquire the knowledge of language from the activity of listening, then they could create words on their mind to deliver their thought through speaking activity. Speaking somewhat becomes a measurement of someone wheter he or she can use the language or not. As stated by Bygate (1997), it is the skill by which they are most frequently judged, and through which they may make or lose friends. Bygate pointed the use of speaking on making friends and he mentioned losing friends at the same time. That is an emphasis that speaking is important in students' daily life. 
Brown (2007: 4) defines speaking as an interactive process of constructing meaning that involves producing, receiving and processing speech of sounds as the main instrument. While Thornbury (2005) says that speaking is an interactive process and requires the a36bility to cooperate in the management of speaking turn. Moreover, Argawati (2014) argues that speaking is an oral expression of an interactive process of constructing meaning which involves phonological and grammatical system and requires the ability to cooperate in the management of speaking turn in order to give information and ideas.

To assess the students ability on speaking, Thornbury (2005: 115) suggest that the teachers need to compile the planning of the assignment in the issue of how to find the right balance between accuracy (vocabulary, grammar, pronunciation) and fluency. However, Argawati adds one point to make it complete and meaningful. The point is comprehension. This is how the students understand what they say during the speaking activity.

\section{Risk-taking}

There are some psychological variable which may influence the students way of learning four basic skills of English, one of them is Risk-taking. Beebe (1983) as cited in Meriem (2015) said risk taking as: "A situation where an individual has to make a decision involving choice between alternatives of different desirability; the outcome of the choice is uncertain; there is a possibility of failure". Risk- taking behavior refers to a "developmental trait that consists of moving toward something without thinking of the consequences" (Alshalabi, 2003, p. 22 as cited in Cervantes, 2013). In addition, Gass \& Selinker (2000) as cited in Burgucu, et.al (2010) state risk-taking is not only one of the dimensions of individual differences (IDs), but also, it is one of the important parts in second language learning process; moreover, it is a language learning strate gy for good language learners who are willing to take risks. Brown (2001: 149) in Argawati \& Suryani (2017) states that risk-taking is an important characteristic of successful learning of a second language which refers to the learner's ability to gamble a bit, to be willing to try out hunches about the language, and take the risk of being wrong. This enables students to try something new and reduce the fear of being wrong.

Liu and Jackson (2008) who stated that there was a significant and positive relationship between language class risk-taking and students' self-rated proficiency in L2 English speaking. In addition, Luft (2007: 2) identifies four characteristics and behaviors related to risk-taking: (1) being willing to appear foolish in order to communicate and get the message across; (2) using the language when not required to do so; (3) being comfortable with uncertainty and willing to try out guesses; and (4) being willing to make mistake in order to learn and communicate.

Based on the theories above, it can be concluded that risk-taking is an important characteristic of successful learning of a second language referring to students' willingness to make decision involving something new and different without putting the primary focus on success or failure. 


\section{RESEARCH METHODOLOGY}

The researchers used quantitative as research method. According to Crowl (1996:as cited in Suryani (2015), "quantitative method is used to examine questions that can be best answered by collecting and statistically analyzing data that are in numerical form". The research design used correlation. Creswell (2012) stated that correlational research design is used to describe and measure the relationship between two or more variables or sets of score without controlling and manipulating the variables as in an experiment. This correlation examines the relationship between psychological variable (Risk-taking) and the dependent variable (speaking ability). There were two variables involved; Risk-taking and speaking ability. The popuation covered all students in the second semester IKIP Siliwangi which consisted of three classes. Each class had 30-40 students. From this population, the sample taken was class A3 with the total students was 30 . The sample was choosen randomly using cluster random sampling. The researchers used two instruments; risk-taking questionnaire and speaking test. The questionnaire used consisted of 26 questions. The questionnaire is presented in table 1 as follows.

\section{Table 1 Questionnaire of Risk-Taking}

\begin{tabular}{|c|c|c|c|c|c|}
\hline \multirow[t]{3}{*}{ No } & \multirow[t]{3}{*}{ Statements } & & \multicolumn{3}{|c|}{ Scores } \\
\hline & & 1 & 2 & 3 & 4 \\
\hline & & $\begin{array}{l}\mathrm{ST} \\
\mathrm{S}\end{array}$ & TS & $S$ & SS \\
\hline
\end{tabular}

1. Ketika saya ragu untuk memberikan respon dalam bahasa Inggris, saya menghindar untuk memberi respon

2. Saya berusaha mengandalkan kemampuan saya sendiri untuk menebak jawaban yang paling besar kemungkinan benarnya

3. Dalam diskusi kelompok, saya tidak akan memberi pendapat lagi ketika ide baru saya ditertawakan

4. Saya tidak menerapkan prinsip "malu bertanya sesat dijalan" karena saya tidak suka bertanya ketika saya merasa ragu

5. Saya tidak pernah merasa frustasi dalam belajar bahasa Inggris meskipun sering berbuat kesalahan

6. Saya merasa malu apabila ide-ide baru yang saya ajukan dalam sebuah diskusi kelompok ternyata ditolak

7. Saya menggunakan bahasa Indonesia untuk mengungkapkan difficult words untuk menghindari kesalahan

8. Saya merasa lebih tertantang apabila berbahasa Inggris dengan teman atau guru yang berlatar belakang bahasa Inggris

9. Saya menggunakan kalimat sederhana untuk menghindari kesalahan meskipun akan mendapat nilai yang tidak maksimal

10. Saya penasaran untuk membaca artikel berbahasa Inggris meski tidak seluruhnya tahu isinya

11. Saya merasa belum siap apabila mendapatkan tawaran untuk mengikuti kompetisi dalam bahasa Inggris

12. Saya selalu memberikan solusi terhadap masalah-masalah kompleks yang sulit dipecahkan dalam kelompok

13. Saya belum percaya diri apabila berbicara bahasa Inggris langsung dengan native speaker

14. Saya berusaha menghindar ketika berbahasa Inggris dengan orang yang menggunakan kalimat yang kompleks

15. Jika saya mendapatkan kesempatan untuk memimpin sebuah diskusi kelompok, saya akan mengambil kesempatan tersebut 
16. Saya tidak suka mengerjakan tugas individu karena saya tidak mau menanggung resiko sendiri ketika salah

17. Saya lebih suka berbicara bahasa Inggris dengan orang yang kemampuannya lebih baik daripada saya

18. Saya tidak percaya diri bila karangan saya ditempel di madding karena jika ada kesalahan akan diketahui banyak orang

19. Jika saya mengajari sesuatu dan salah maka saya tidak akan Membetulkannya

20. Saya tidak pernah merasa putus asa belajar bahasa Inggris meskipun telah membuat banyak kesalahan

21. Ketika saya membuat kesalahan, saya akan mengalihkan topic sehingga kesalahan saya tidak mendapat perhatian

22. Saya hanya siap menyatakan pendapat saya dalam bahasa Inggris jika materinya sudah disiapkan terlebih dahulu

23. Dalam melakukan kegiatan speaking, saya tidak perlu membuat outline apa saja yang akan saya ungkapkan

24. Saya mengatakan kosakata baru dalam bahasa Inggris secara berulang-ulang tanpa suara sebelum saya menggunakannya

25. Saya akan mengambil setiap kesempatan untuk pengalamanpengalaman baru agar kemampuan bahasa Inggris saya senantiasa berkembang

26. Setiap menemui kosakata baru, saya akan melatih untuk mengucapkannya terlebih dahulu sebelum menggunakannya saat kegiatan speaking

The questions on the questionnaire served in Bahasa Indonesia. It was done to avoid missunderstanding of the students. The researchers wanted to make sure that all of the students understand the questions so that they could easily answer the questions without hesitation. It was hoped that the result really reflect the condition of the students especially in relation to their level of risk-taking.

Meanwhile, the speaking test was an instruction for the students to describe their favorite activities during college break. Grading was based on the scoring rubrics by Hughes (2003) as described in table 2 below.

Table 2

Scoring Rubrics for Speaking Test

\begin{tabular}{cccl}
\hline No. & Aspect & Score & \multicolumn{1}{c}{ Criteria } \\
\hline 1. & Grammar & 1 & $\begin{array}{l}\text { Grammar almost entirely inaccurate except in stock } \\
\text { phrases } \\
\text { Contrast errors showing control of very few major } \\
\text { patterns uncontrolled and frequently preventing } \\
\text { communication }\end{array}$ \\
3 & $\begin{array}{l}\text { Frequent errors showing some major patterns } \\
\text { uncontrolled and Causing occasional irritation and } \\
\text { misunderstanding } \\
\text { Occasional errors showing imperfect control of some } \\
\text { patterns but no weakness that causes misunderstanding }\end{array}$
\end{tabular}




\begin{tabular}{|c|c|c|c|}
\hline & & 5 & Few errors, with no pattern of failure \\
\hline & & 6 & No more than two errors during speaking \\
\hline \multirow[t]{6}{*}{2.} & Vocabulary & 1 & $\begin{array}{l}\text { Vocabulary inadequate for even the simplest } \\
\text { conversation }\end{array}$ \\
\hline & & 2 & $\begin{array}{l}\text { Vocabulary limited to basic personal and survival areas } \\
\text { (time, food, transportation, family, etc) }\end{array}$ \\
\hline & & 3 & $\begin{array}{l}\text { Choice of words sometimes inaccurate, limitations of } \\
\text { vocabulary prevent discussion of some common } \\
\text { professional and social topics }\end{array}$ \\
\hline & & 4 & $\begin{array}{l}\text { Professional vocabulary adequate to discuss special } \\
\text { interests; general vocabulary permits discussion of any } \\
\text { non-technical subject with some circumlocutions }\end{array}$ \\
\hline & & 5 & $\begin{array}{l}\text { Professional vocabulary broad and precise; general } \\
\text { vocabulary adequate to cope with complex practical } \\
\text { problems and varied social situation }\end{array}$ \\
\hline & & 6 & $\begin{array}{l}\text { Vocabulary apparently as accurate and extensive as that } \\
\text { of an educated native speaker }\end{array}$ \\
\hline \multirow[t]{6}{*}{3.} & Fluency & 1 & $\begin{array}{l}\text { Speech is halting and fragmentary that conversation is } \\
\text { virtually impossible }\end{array}$ \\
\hline & & 2 & $\begin{array}{l}\text { Speech is very slow and uneven except for short or } \\
\text { routine sentences }\end{array}$ \\
\hline & & 3 & $\begin{array}{l}\text { Speech is frequently hesitant and jerky; sentences may } \\
\text { be left uncompleted }\end{array}$ \\
\hline & & 4 & $\begin{array}{l}\text { Speech is occasionally hesitant, with some unevenness } \\
\text { caused by rephrasing and grouping for words }\end{array}$ \\
\hline & & 5 & $\begin{array}{l}\text { Speech is effortless and smooth, but perceptively non- } \\
\text { native in speed and evenness }\end{array}$ \\
\hline & & 6 & $\begin{array}{l}\text { Speech on all professional and general topics as } \\
\text { effortless and smooth as a native speaker's }\end{array}$ \\
\hline & Comprehension & 1 & $\begin{array}{l}\text { Understands too little for the simplest type of } \\
\text { conversation }\end{array}$ \\
\hline & & 2 & $\begin{array}{l}\text { Understand only slow, very simple speech on common } \\
\text { social and touristic topic; request constant repetition } \\
\text { and rephrasing }\end{array}$ \\
\hline & & 3 & $\begin{array}{l}\text { Understands careful, somewhat simplified speech when } \\
\text { engaged in a dialogue, but may be require considerable } \\
\text { repetition and rephrasing }\end{array}$ \\
\hline & & 4 & $\begin{array}{l}\text { Understand quite well normal educated speech when } \\
\text { engaged in a dialogue, but requires occasional } \\
\text { repetition or rephrasing }\end{array}$ \\
\hline & & 5 & $\begin{array}{l}\text { Understands everything in normal educated } \\
\text { conversation except for very colloquial or low- } \\
\text { frequency items, or exceptionally rapid or slurred } \\
\text { speech }\end{array}$ \\
\hline & & 6 & $\begin{array}{l}\text { Understands everything in both formal and colloquial } \\
\text { speech to be expected of an educated native speaker }\end{array}$ \\
\hline \multirow[t]{3}{*}{5.} & Pronunciatio $\mathrm{n}$ & 1 & Pronunciation frequently unitelligible \\
\hline & & 2 & $\begin{array}{l}\text { Frequent gross errors and very heavy accent make. } \\
\text { Understanding difficult, require irrequent repetition }\end{array}$ \\
\hline & & 3 & $\begin{array}{l}\text { Foreign accent" requires concentrated listening, and } \\
\text { mispronunciation lead to occasional misunderstanding. } \\
\text { Apparent errors in grammar and vocabulary }\end{array}$ \\
\hline
\end{tabular}




\begin{tabular}{cl}
\hline 4 & $\begin{array}{l}\text { Market "Forget accent" and occasional } \\
\text { mispronunciation which do not interfere with } \\
\text { misunderstanding } \\
\text { No conspicious mispronunciations, but would not be } \\
\text { taken for a native speaker } \\
\text { Native pronunciation, with no trace of "Foreign accent" }\end{array}$ \\
\hline
\end{tabular}

The grade of this speaking test was done collaboratively between the two researchers. The final score was the result of the combination score by the researchers as graders then devided by two. The data collected, both the score of the questionnaire and the score of speaking test, were then analysed through several steps using SPSS 19. The first one, the data were tested the normality of them. If the data were in a normal distribution, the calculation would be continued using Pearson product Moment.

\section{FINDINGS AND DISCUSSION}

The researchers applied speaking test for gathering the score of speaking, and gave risktaking questionnaire to determine the students level of risk-taking. Those two steps were conducted in the target class which consist of 30 students. Here are the result of the speaking test and the answer of risk-taking questionnaire.

\section{Speaking test}

Speaking test was conducted on the thirty students orally using instruction. It was done in the same day so that the students did not have differrent time to prepare. The students then explained their answer one by one in front of the two researchers. The scoring rubric used was based on the instrument prepared above. It took approximately 3-5 minutes for each student to perfom their speech. They showed various attitude towards the test. Some studens felt nervous, but not few of them who enjoyed the test given by the researchers. From the test, we could see the students' profile of speaking ability as shown by Figure 1.

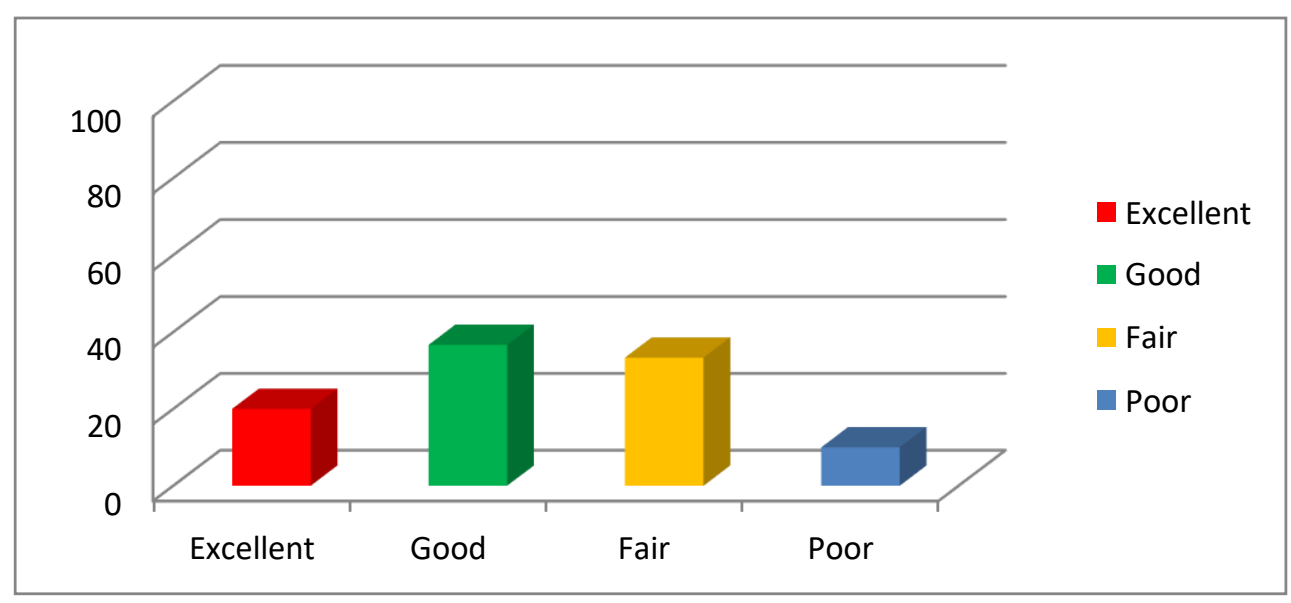

Figure 1. The Students' Profile of Speaking Ability 
From thirty students in that class, $20 \%$ (6 students) gained $>80$ on speaking test; $36.67 \%$ (11 students) got 70-80, 33.3\% (10 students) got 60-70, and only 10\% (3 students) out of them reached $<60$.

Second instrument provided by the researchers was questionnaire of risk-taking. The questionnaire used was taken from the research conducted by Argawati and Suryani (2017) which had already been tried out to another class. Therefore, it was already valid and reliable. This questionnaire consisted of 26 item of questions which served four aspects of risk-taking. The profile of students' level of Risk-taking based on thore aspect can be seen on figure 2 below.

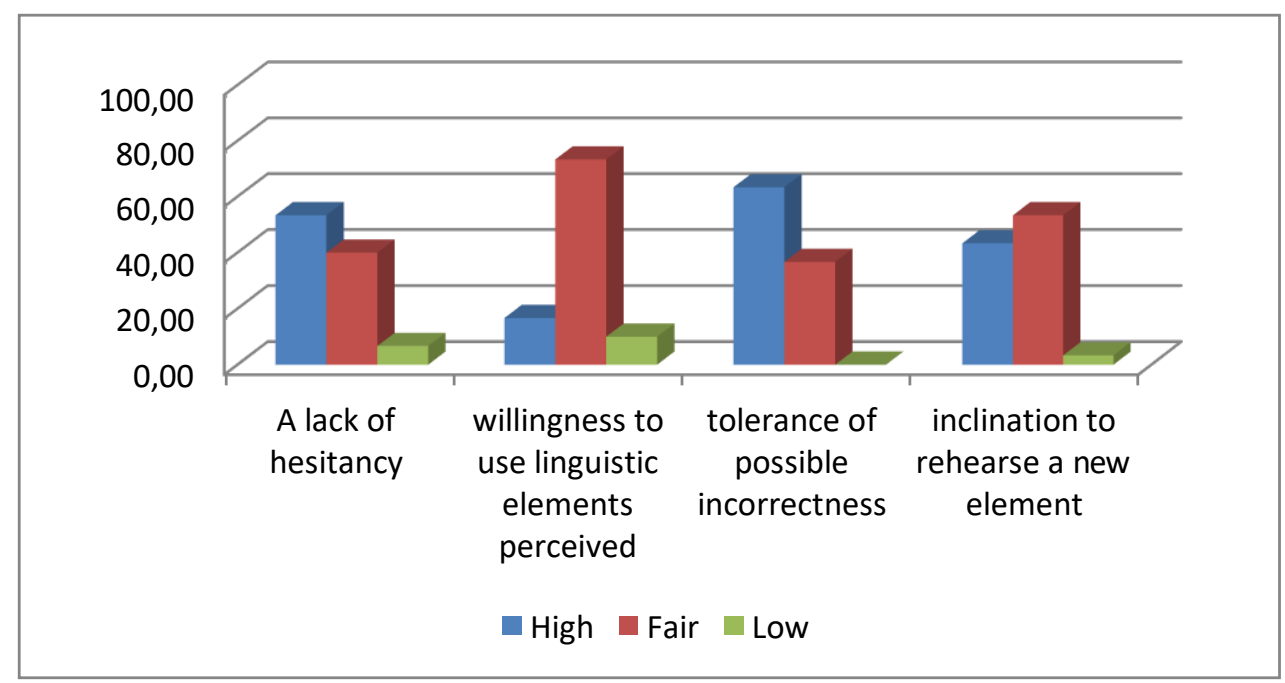

Figure 2. Result of Risk-taking based on the four aspect

Table 3 above shows the profile of students' risk-taking viewed from each aspect, namely: a lack of hesitancy, willingness to use linguistic elements, tolerance of possible incorrectness, and inclination to rehearse a new element. We can see there that all of the four aspects, only few students who showed a low level of risk-taking; even, there is no students who were low on tolerance of incorrectness. It means that all of them had feeling that doing incorrectness is not always a problem so that they feel that others can tolerate it.

Moreover, the result of the overall score of risk-taking questionnaire is presented in figure 3 below.

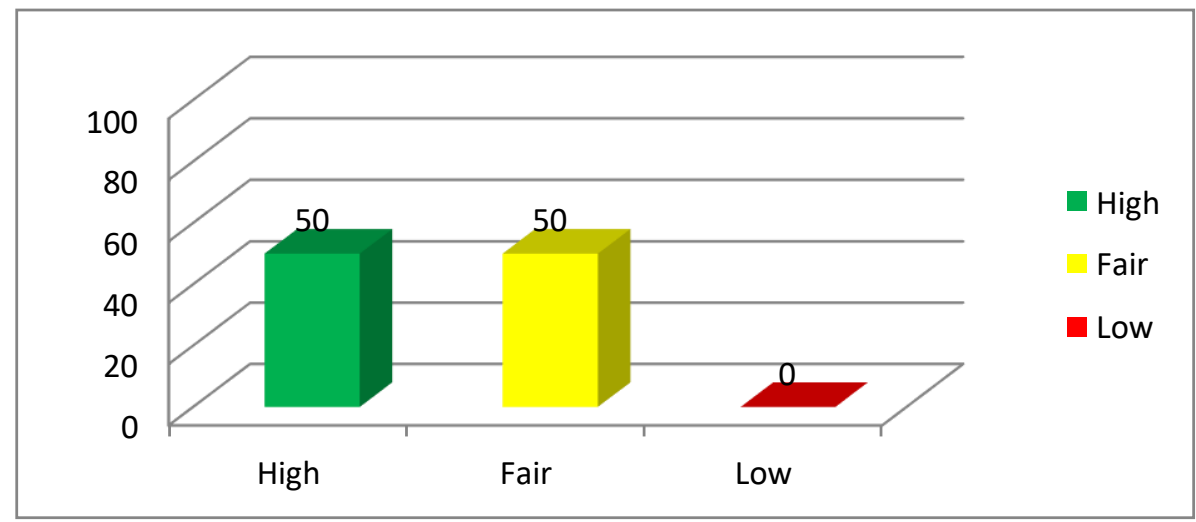


From the figure above, we can see that $50 \%$ students had high level of risk-taking, and $50 \%$ had a fair level of risk-taking. Students with low level of risk-taking is $0 \%$. There was no students with low level of risk-taking. Then, we can conclude that this class has a good level of risk-taking since they did not show the students with low level of it.

\section{Normality Test}

After gaining the score of speaking and score of risk-taking, the next step done was the test of normality to identify whether or not the data were in normal distribution. Below is the table 3 which showed the result of normality test conducted by the researchers.

Table 3

Tests of Normality

\begin{tabular}{|c|c|c|c|c|c|c|}
\hline & \multicolumn{3}{|c|}{ Kolmogorov-Smirnov ${ }^{\mathrm{a}}$} & \multicolumn{3}{|c|}{ Shapiro-Wilk } \\
\hline & Statistic & $\mathrm{df}$ & Sig. & Statistic & df & Sig. \\
\hline Risktaking &, 123 & 30 & ,200* &, 944 & 30 &, 115 \\
\hline Speaking &, 118 & 30 & ,200* & 967 & 30 & ,457 \\
\hline
\end{tabular}

a. Lilliefors Significance Correction

*. This is a lower bound of the true significance.

Based on the table above we can gain information relates to the result of normality test. Both risk-taking and speaking capability gained 0.200 which more than the level of significant $0.05(5 \%)$. Therefore we can conclude that the data were in normal distribution. Due to the data were in normal distribution, the next test conducted was correlation test using pearson product moment. After calculating the data from both score of risk-taking and speaking test, the researchers revealed the result as presented in table 4 below.

Table 4

\section{Result of Correlations Test}

\begin{tabular}{|cl|r|r|}
\hline & Risk taking & Speaking \\
\hline Risk taking & Pearson Correlation & 1 &, $685^{* *}$ \\
& Sig. (2-tailed) & &, 000 \\
& $\mathrm{~N}$ & 30 & 30 \\
\hline
\end{tabular}




\begin{tabular}{|ll|r|r|}
\hline Speaking & Pearson Correlation &, $685^{* *}$ & 1 \\
& Sig. (2-tailed) &, 000 & \\
& $\mathrm{~N}$ & 30 & 30 \\
\hline
\end{tabular}

The result showed that the sig. 2-tailed both risk-taking and speaking are 0.000 lower than the level of significant (0.05). By this calculation, Null hypothesis (Ho: there is no correlationbetween Students'level of risk-taking and their ability on Speaking) is rejected. It means that there is a correlation between Risk-taking and Speaking ability. Then, based on Cohen (1988:79-81), if the Pearson correlation is among 0.50-1.0, we can say that the correlation between those two variables is large.

\section{E. CONCLUSIONS}

English language Students in Indonesia clearly need to improve their ability or mastery on the four basic skills of english. From those basic skills, speaking is considered the most difficult skill to improve. It needs both macro and micro skills of speaking. It does stop there. The language learners should maintain their courage to deliver the idea. If they can do it well, the mastery of speaking will be reached. However, many problems accurred during the teaching and learning process. Beside method, technique, media or approach of teaching, students' psychological issues do affect their way of learning. One of these psychological issues is Risk-taking.

This research aims on examining the correlation between risk-taking on the students' level of speaking ability. The sampel was 30 students from second semester. All of them were asked to to two difference tests; speaking test and risk- taking test. The speaking test used instruction to the students to make a speech on their favourite activities during the scholl break, while the risk-taking test was through questionnaire which consisted of 26 questions and was built based on four aspect decide by some experts.

The result reveal that Null Hypothesis was rejected which means there is a positive correlation between risk-taking and students' speaking ability. From this result, we can understand something. Students with high lebvel of risk-taking will tend to try to do more, in this case is speaking. He or she will be encouraged to produce new and more vocabularies to built up their sentences without feeling hesitate. By doing all of that, they will understand the feeling of creating some sentences by their own. If the sentences are correct, it will encourage them more. However, if the sentences are wrong it will not affect their motivation since they have tolerance of incorrectness and they will keep trying. If the students keep trying on speaking, it will build their courage more and more and automatically will improve their way of saying something, in other word their speaking ability.

Therefore, it can be concluded that the students with high level of risk-taking, they will create more opportunity to improve themselves on building sentences and increase their conficence on saying the words into sentences. Shortly, students with high level of risktaking will have a good speaking ability. 
From the conclusion gained by the researchers, some suggestions are then formulated. First, teachers need to improve the students' level of risk-taking first if they want to make the students improve the speaking ability. It can be done by choosing such method which can accomodate the students need of trying something new. Second, the students themselves should realize that by trying more, they can create and speak more English words and sentence, so they need to have willingness to improve their level of risk-taking to then improve their ability of speaking.

\section{REFERENCES}

Argawati, N. O. (2014). Improving Students'speaking Skill Using Group Discussion (Experimental study on the First Grade Students of Senior High School). ELTIN JOURNAL, 74-81.

Argawati, N. O., \& Syahrizal, T. (2016). The Use of Task-Based Instruction to Improve Speaking Skill to the Second Semester Students of STKIP Siliwangi Bandung on the Academic year of 2014-2015. Jurnal P2M STKIP Siliwangi.

Argawati, N. O., \& Suryani, L. (2017). Teaching Writing Using Think-Pair-Share viewed from Students' Level of Risk-Taking. ERJEE, 109-116.

Bang, Y. (1999). Factors affecting Korean students' risk-taking behavior in ESL classroom. Dissertation. Ohio University. Ohio. Retrieved from http://etd.ohiolink.edu/view.cgi?acc_num=osu1243019322

Boonkit, K. (2010). Enhancing the Development of Speaking Skills for Non Native Speaker of English. Procedia Social and Behavioral Science, 1305- 1309.

Brown, H. D. (2001). Teaching by principles: An Interactive Approach to Language Pedagogy. San Francisco: Pearson Education, Inc.

Brown, H.D. (2007). Principles of Language Learning and Teaching. New York: Pearson Education, Inc.

Burgucu, A. et. al. (2010). Who are Our Students? Investigating Learners' Risk Taking Ability and Achievement on Second Language Acquisition. 2nd International Symposium on Sustainable Development. Taken from http://eprints.ibu.edu.ba/320/1/ISSD2010Socialscience_p1-p6.pdf

Bygate, M. (1997). Speaking. New York: Oxford University Press

Cervantes, I.M. (2013). The Role of Risk-Taking Behavior in the Development of Speaking Skills in ESL Classrooms. Revista de Lenguas Modernas, No. 19, 421435.

Cohen. (1988). SPSS survival manual: a step by step guide data analysis using SPSS for windows third edition. New York: Open University Press.

Creswell, J.W. (2012). Educational research. Buston: Pearson Education. Hasanah, H. U. (2017). Teaching Speaking Using Tea Party Technique. OKARA: Jurnal Bahasa dan Sastra, Vol. 11, No. 2, November 2017, 263-276. 

Hughes, A. (2003). Testing for language teachers. Cambridge: Cambridge University Press.

Liu, M., \& Jackson, J. (2008). An exploration of Chinese EFL learners' unwillingness to communicate and foreign language anxiety. The Modern Language Journal, 92(1), $71-86$

Luft, S. (2007). Language classroom risk-taking behavior in a performed culture based program. Thesis, School of the Ohio State University. Retrieved on August, 2012 from http://etd.ohiolink.eduview,cgiacc.num= osul 1229701363.

Maeng, U. (2008). English Teachers' Language Anxiety in the Intensive Teacher Training Program and in the Classroom. English Language \& Literature Teaching, 14(149-172).

Meriem, B. (2015). The Effects of Risk Taking on the Learning of Spoken English at University. Expression: Juny No 1, p 84- 94

Suryani, L. (2015). The effectiveness of role play in teaching speaking. ELTIN Journal, October, volume 3/II, 106-109.

Thornbury, S. (2005). How to teach speaking. New York: Pearson Education Inc.

Zhang, Y. (2009). Reading to speak: intergarating oral communication skills.

English Teaching Forum , 42-43. 